\title{
Nitrate Residues in Fruits, Vegetables and Bread Samples and Their Health Consequences
}

\author{
Yasser El-Nahhal \\ Department of Toxicology and Environmental Chemistry, Faculty of Science, The Islamic University of Gaza, Gaza, Palestine \\ Email: y_el_nahhal@hotmail.com
}

How to cite this paper: El-Nahhal, Y. (2018) Nitrate Residues in Fruits, Vegetables and Bread Samples and Their Health Consequences. Health, 10, 487-501.

https://doi.org/10.4236/health.2018.104039

Received: March 19, 2018

Accepted: April 27, 2018

Published: April 28, 2018

Copyright $\odot 2018$ by author and Scientific Research Publishing Inc. This work is licensed under the Creative Commons Attribution International License (CC BY 4.0).

http://creativecommons.org/licenses/by/4.0/

(c) (i) Open Access

\begin{abstract}
Application of mineral fertilizers such as Nitrate or urea derivatives to crops is an essential agricultural step for fruits and vegetable production. This step may lead to accumulation of Nitrate levels in fruit and vegetables creating health risks such as cancer. This study aimed to determine nitrate residues in beard, fruits, vegetable and water samples collected from different locations and to correlate them with potential cancer cases in Gaza. Results showed elevated levels of Nitrate in some breads samples and all fruits, vegetable and water samples. This suggests high potential risk of population to cancer cases. So far, the growing incidence of cancer cases in Gaza strip may be attributed to high level of nitrate contents in bread, fruits, vegetable and water samples. It is recommended to exclude nitrate fertilization from agricultural process or replace it with other $\mathrm{N}$-fertilizer source.
\end{abstract}

\section{Keywords}

Nitrate Residues, Cucumber, Tomato, Fruits

\section{Introduction}

Contamination of food is a worldwide problem. Contamination of food may occur directly on the field throughout agricultural steps such as pesticide and fertilizers application, indirectly throughout postharvest applications of preservatives and/or throughout processing steps. So far food contamination can be subdivided into three main categories: 1) organic contamination of food, which includes pesticide residues, antibiotics, preservatives; 2) inorganic contamination such as heavy metals, nitrates, phosphates and; 3) organometallic contaminations.

So far organic contamination of food samples with pesticides has intensively 
studied. This included determination of dioxins, dibenzofurans and poly chlorinated biphenyls (PCBs) in human human milk and food [1] [2] pesticide residues in cucumber, tomatoes, strawberries, green pepper, potatoes, Vicia faba, green bean and green peas [3]-[8], leachate of solid wastes [9] [10], herbicide residues in water [11]-[23].

Furthermore, inorganic contamination included heavy metals in water samples [24] [25], vegetables [26] [27] [28] [29]. These studies found considerable concentrations of heavy metals in water samples and found nitrate levels exceeded the maximum residue limits set by USEPY. Additionally, some authors investigated the health impacts associated with these contaminants. The investigators found oxidative stress among general populations [30]-[35], impaired human health effects [36] [37] [38] [39] [40], toxicity to non-target organism [41]-[48]. Gaza Strip has an intensive agricultural activity to secure vegetables, fruits and bread to the local population. This activity has been associated with intensive application of mineral fertilizers such as the use of large quantiles of nitrate along with phosphate as inorganic fertilizers. Application of fertilizers in Gaza Strip raised public concern on Nitrate concentration in fruits, vegetables and bread and their health consequences.

Cancer cases in Gaza Strip are progressively increased; the incidence rate reached high level of Ministry of Health [49]. Previous studies correlated the incidence of cancer cases with pesticide application [38] [50] and/or medical exposure treatments [51]. Furthermore, it can be suggested that a correlation between nitrate levels in food and cancer cases are existed. Previous authors [52] correlated cancer cases with nitrate levels in food. So far, few reports around the world and no reports published from Gaza on nitrate levels in bread, fruits and vegetables are available and their health consequences. Residues of nitrate in bread, fruits and vegetables are poorly investigated or remains on its primary stages. The author of this study focused his efforts on nitrate determination in beard, fruits and vegetables for the possibility to respond to the growing concern of public about nitrate residues in food samples.

\section{Materials and Methods}

Description of study site. Gaza Strip is an important part of Palestine. It contained five Governorates, the northern area, Gaza, the middle (Deir al-blah), Khan Yunis and Rafah Governorates. The Gaza Strip, as one of the most densely populated areas in the world $\left(2638\right.$ people $\left./ \mathrm{km}^{2}\right)$, has limited and declining resources and has already started to experience deterioration of environmental quality. More details on study site are shown in recently published work [8].

\section{Experimental Design}

\subsection{Data Collection}

Data on Nitrate fertilizers used in agricultural crops were collected from ministry of agriculture, Gaza Palestine. 


\subsection{Determination of Nitrate Levels}

\subsubsection{Bread Samples}

Bread samples were collected from main five big bakeries from Gaza city where most inhabitants purchased their daily bread. About 5 bags $(3 \mathrm{~kg}$ each and counted 50 bread pieces) were collected from each bakery house through two hours during the intensive period of work to insure randomization of bread selection.

The samples of each bakery were brought to the laboratory, mixed thoroughly then, three samples $1 \mathrm{~kg}$ each were randomly collected from the 5 bags of each bakery house. Each $1 \mathrm{~kg}$ of bread sample was transferred to a 3 litter glass conical flask. Two litter of distilled water was added to each flask and left for four hours then the total volume of water and bread was brought to $3 \mathrm{~L}$ by adding distilled water up to the mark. The flasks were left under magnetic stirring for an overnight period. Then bread water solution was separated by centrifugation at $3000 \mathrm{~g}$ for $15 \mathrm{~min}$ at $10^{\circ} \mathrm{C}$. Nitrate concentrations in the superintendents were determined using salicylic acid method [28] [29]. The analysis included 15 replicates.

\subsubsection{Fruits Samples}

Representative samples (15 samples, $3 \mathrm{~kg}$ each) tomato, Solanum lycopersicum, cucumber Cucumis sativus, samples, sugar cane Saccharum spontaneum L. and pomegranate Punica granatum samples were randomly selected and purchased from the central market in Gaza and stored in the laboratory at our university. The samples were coded according to the laboratory procedure. One kg tomato and/or cucumber was added to one litter distilled water and crushed using a blinder for $15 \mathrm{~min}$. Then the mixture was homogenized using a special homogenizer. Then the supernatants were collected using centrifugation method at 5000 $\mathrm{g}$ for $20 \mathrm{~min}$ at $10^{\circ} \mathrm{C}$. The analysis included 15 replicates.

Sugar cane and pomegranate fruits were squeezed using a special device for each of them. The supernatant was cleaned up by filtration using normal filter paper.

Nitrate levels in the supernatants were determined by salicylic acid method as mentioned above [28]. The analysis included 13 replicates.

In this method Nitrate concentration were allowed to react with salicylic acid to form nitro-salicylic acid in the presence of sulfuric acid. The nitro salicylic acid is colorless in the acidic media where the reaction took place. Then a sodium hydroxide was added to the solution to neutralize the sulfuric acid. At neutralization, a yellow color would appear and its intensity represents the concentration of nitrate in the solution. More details are shown in the following equations

$$
\begin{aligned}
& \mathrm{NO}_{3}+\text { Salicylic acid }+ \text { Sulfuric acid } \rightarrow \mathrm{P} \\
& - \text { Nitro }- \text { Salicylic acid }+ \text { Sulfuric acid } \\
& (\text { Equation } 1)+\mathrm{NaOH} \rightarrow \mathrm{P}-\mathrm{Nitro}-\text { Salicylic } \\
& \text { acid (yellow color) }+\mathrm{H}_{2} \mathrm{O}+\mathrm{Na}_{2} \mathrm{SO}_{4}
\end{aligned}
$$


The yellow color is being determined by spectrophotometer at $420 \mathrm{~nm}$.

\subsubsection{Water Collection}

Water samples were collected from the bakery themselves and analyzed for $\mathrm{Ni}$ trate levels. Additionally, water samples were collected from local wells supplying human consumption. Nitrate levels were analyzed as mentioned above.

\subsection{Statistical Analysis}

Mean and standard deviation were calculated for each type. T-test was used to detect significant differences among means. P-value $=0.05$ or less indicates significant differences.

\section{Results}

\subsection{Nitrate Fertilizers}

Nitrate fertilizers used in agricultural crops are shown in Table 1. It can be seen that large fraction of nitrogen fertilizers (urea and organic fertilizers) were applied in the tested agricultural produces. The amounts of fertilizers can slowly be converted to nitrate in soil and become available for plant uptake.

\subsection{Nitrate Levels in Bread}

Nitrate levels in bread samples are shown in Figure 1. It is obvious that nitrate levels in all bread samples are below $20 \mathrm{mg} / \mathrm{kg}$ except bread from Gaza-Y has Nitrate level above $60 \mathrm{mg} / \mathrm{kg}$.

Furthermore, statistical analysis detected significant differences only with Gaza-Y bread. So far we marked the data with different letter where statistical analysis was detected.

\subsection{Nitrate Level in Fruits and Vegetables}

Nitrate levels in cucumber, tomato (vegetables) and sugar cane, pomegranate (fruits) some fruits and vegetables are shown in Figure 2.

It is obvious that Nitrate concentrations exceeded the maximum residue limit set by USEPA and WHO for nitrate concentration in drinking water quality. Regardless to the fact that these products are not drinking water but water consist more that 90 of its contents. Consequently, we can apply drinking water standards to judge the quality for human consumption. It can be seen that Table 1. Nitrate fertilizers in agricultural crops.

\begin{tabular}{ccc}
\hline Crop & Urea $46 \%(\mathrm{~kg} / \mathrm{ha})$ & Organic N \\
\hline Cucumber & 130 & 500 \\
Tomato & 220 & 500 \\
Sugar cane & 200 & 500 \\
Pomegranate & 200 & 500
\end{tabular}




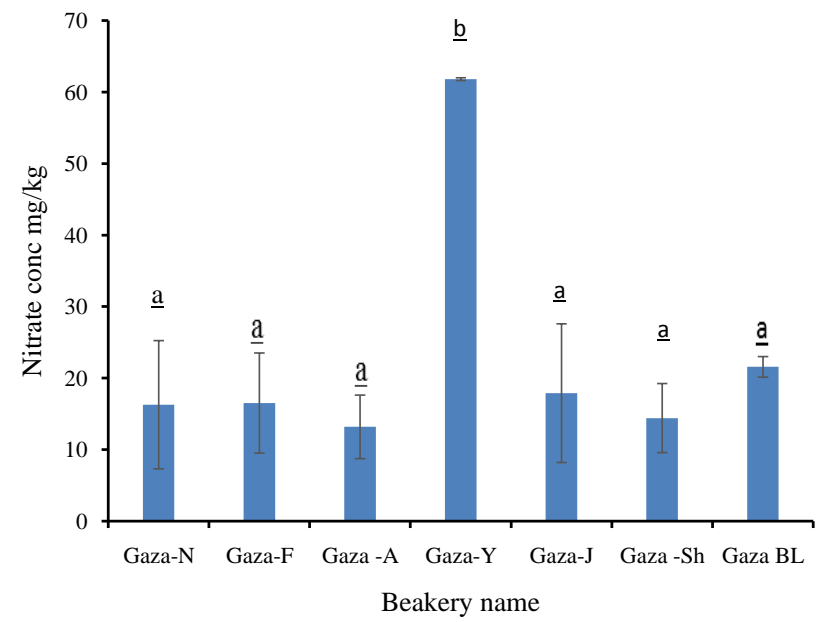

Figure 1. Nitrate levels in bread samples collected from different bakeries in Gaza strip. Error bars represent standard deviation. Columns have the same letter are not significantly different at P-vale $=0.05$.

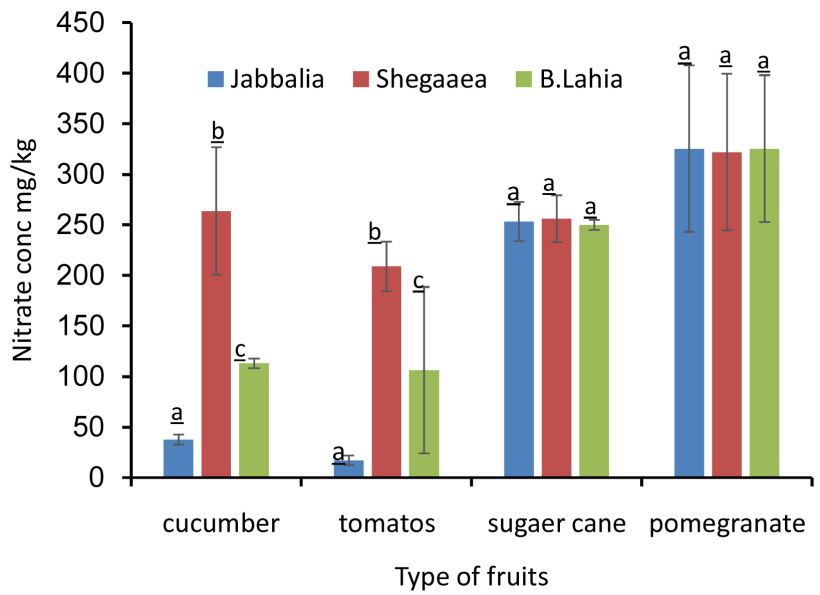

Figure 2. Nitrate levels in different fruits and vegetables from different locations. Error bars represent standard deviation. Columns have the same letter are not significantly different at $\mathrm{P}$-value $=0.05$.

significant differences in nitrate levels were detected in cucumber and tomato obtained from different locations. This suggests different nitrate application and uptake by plants. So far fruit samples did now show significant difference among locations. This suggests that similar nitrate program was applied for fruits in different location.

\subsection{Nitrate Levels in Water}

Nitrate levels in drinking water are shown in Figure 3. It is obvious that Nitrate level exceed WHO standards [53]. These data suggest high potential risk to local inhabitant who used large fraction of water.

\subsection{Cancer Cases in Gaza Strip}

Cancer cases registered in Gaza strip during 2009-2014 are listed in Table 2. 
Table 2. Cancer case registered in Gaza 2009-2014 [49].

\begin{tabular}{|c|c|c|c|}
\hline \multirow[b]{2}{*}{ Type of cancer } & \multicolumn{3}{|c|}{ Incidence rate case $/ 100,000$} \\
\hline & Children $(\mathrm{n}=476)$ & Male $(\mathrm{n}=3219)$ & Female $(\mathrm{n}=3850)$ \\
\hline Breast cancer & - & - & $49.1(\mathrm{n}=1283)$ \\
\hline Colo-rectal & - & $45.3(\mathrm{n}=378)$ & $42.7(\mathrm{n}=709)$ \\
\hline Lung & - & $44.9(\mathrm{n}=370)$ & 18.8 \\
\hline Prostate & - & 32.4 & - \\
\hline Thyroid & - & - & 32.4 \\
\hline Leukemia & 24.5 & 30.1 & 29 \\
\hline Lymphoma & 11.6 & 28.6 & 21 \\
\hline Brain & 16.3 & 25.5 & 18.3 \\
\hline Neuroblastoma & 6.1 & 10.1 & - \\
\hline Nephroblastoma & 5 & - & - \\
\hline Rhabdomyosarcoma & 2 & - & - \\
\hline Retinoblastoma & 1.4 & - & - \\
\hline Urinary bladder & - & 21.4 & - \\
\hline Stomach & - & 17.4 & $13.8(\mathrm{n}=227)$ \\
\hline Bone & 6.3 & 11.3 & 10.5 \\
\hline Uterus & - & - & 21.9 \\
\hline Ovary & - & - & 16.3 \\
\hline
\end{tabular}

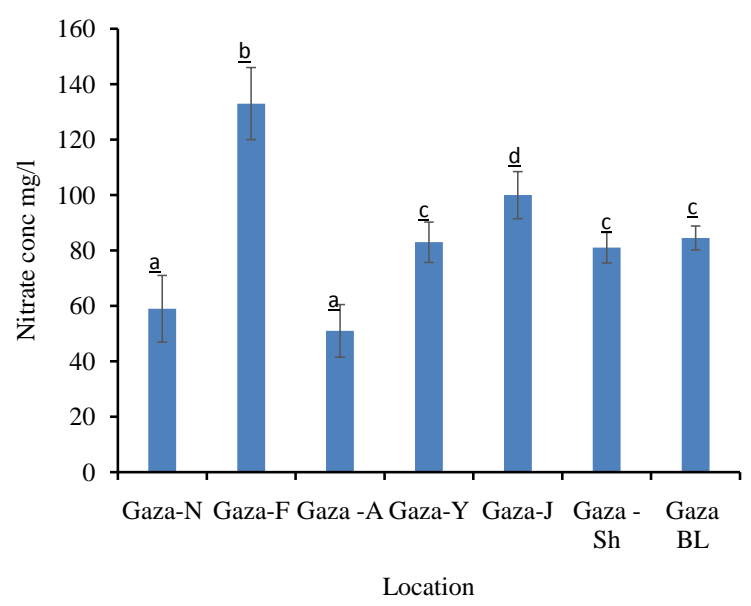

Figure 3. Nitrate levels in water samples from different locations. Error bars represent standard deviation. Columns have the same letter are not significantly different at P-value $=0.05$.

Table 2 shows the incidence of cancer among population. It is clear that there is a growing incidence of cancer among population.

\section{Discussion}

Nitrates and nitrogen containing fertilizers are essential plant nutrient. These 
elements may occur naturally in soil due to geochemical cycle of Nitrogen gas or manmade fertilization. This may result in accumulation of Nitrate levels in fruit and vegetables. The presented data in Table 1 clearly showed the large fraction of both types of nitrogen fertilizers that can be converted to Nitrate in soil and be absorbed by plant root systems. However, the conversions of these fertilizers to nitrate are a slowly process and depend on soil type. So far, plants can absorb all nitrate concentrations from soil and accumulate them in plant tissues as seen in the data in Figure 2 and Figure 3. Furthermore, presented results in Figure 1, clearly demonstrates elevated levels of Nitrate in bread samples from different bakeries in Gaza. Regardless to the fact that the apparent level is nearly low, it can be at high risk to the local inhabitant due to the fact that bread is the main food that everybody consumes at least $0.75-1 \mathrm{~kg} /$ day/person. This tends to be high level. However, the nitrate residues in bread samples may be originated from water irrigation of wheat during agricultural processes or from water used for processing bread in different bakeries. This is supported by the data in Figure 2 and Figure 3. This is also obvious from the data in Figure 2 which shows high residue levels of nitrate in agricultural produces and high level in drinking water (Figure 3). Due to high daily intake of nitrate throughout bread consumption the local population may be exposed to potential hazardous reactions in human body that lead to cancer cell generation.

However, bread consumption with a high level of Nitrate may expose the stomach to form massive cancer cells. It is well known in the literature that bread stays at least $6 \mathrm{hr}$ retention time in the stomach for acid digestion. This process may result in releasing Nitrate contents of food to the stomach and be absorbed and translocated to the liver, then be exposed to oxidase enzymes and be converted to Nitrite radical species or reactive oxygen species (ROS) that may react with the genetic memory of cell (RNA/DNA) forming nitrification product according to the Equation (3) and Equation (4):

$$
\begin{gathered}
\mathrm{NO}_{3}+\text { Oxidase Enzyme in liver } \rightarrow \mathrm{NO} \cdot 2 \\
\mathrm{NO} \cdot 2+\mathrm{RNA} / \text { DNA } \rightarrow \text { RNA-NO2 + DNA-NO2 }
\end{gathered}
$$

It is obvious from Equation (3) that the formation $\mathrm{ROS}\left(\mathrm{NO}_{2}\right)$ depends on the initial concentration of $\mathrm{NO}_{3}$, as much bread being consumed as much of $\mathrm{NO}_{3}$ excreted to the stomach, then the reaction proceed as in Equation (4). Our equations are in accordance with Sun et al. [54] who found different RNA sequencing due to exposure to nitrite concentrations in the range of $0.1-30 \mathrm{mg} / \mathrm{l}$. additional supports to the equations can be obtained from Sun et al. [55] who revealed the influence of ROS generated in response to nitrite on oxidative stress defenses and the antioxidant system in Megalobrama amblycephala, the full length cDNA sequences.

It has been found that generation of ROS may lead to potential oxidative damage to cellular macromolecules [56]. So far, elimination of excessive ROS and protect the human body is depending on the activity of the defense systems which included antioxidant molecules like glutathione or antioxidant enzymes 
such as superoxide dismutase, catalase and glutathione peroxidase [57] [58] [59] [60]. At normal activity of activity those molecules no damage may occur, but at partial or failure elimination of ROS may lead to oxidative damage [61] resulting in cancer cell formation.

So far, nitrite was shown to react with nitrostable compounds in human stomach to form nitroso compounds, many of these $\mathrm{N}$-nitroso compounds have been found to be carcinogenic in all tested animals [53]. Thus a link between cancer risk and endogenous nitrosation as a result of high consumption of foods (bread, vegetables, fruits and drinking water) containing nitrate and/or nitrite and nitrostable compounds is possible [62] [63] [64].

So far, the nitro ribonucleic acid or nitro deoxyribonucleic acid began to grow independently far away from body control forming the $1^{\text {st }}$ cancer cell that starts its growth resulting in a carcinoma growth that may lead to a massive cancer growth.

However, this reaction may take place in the liver forming liver cancer, or in lung forming a lung cancer and so on. This is in accordance with El-Nahhal and Lubbad [34] who found potential metabolic reactions of low concentrations of pesticide in chicken lever.

However, in less acid stomach, minority of population, bread content of nitrate may move to the intestine where the coliform bacteria are commonly residing, in this case nitrate may be reduced to molecular nitrogen and being execrated outside the body according to Equation (5) and Equation (6).

$$
\begin{gathered}
\mathrm{NO}_{3}+\text { COLIFORM BACTERIA } \rightarrow \mathrm{NH}_{4} \mathrm{OH} \\
\mathrm{NH}_{4} \mathrm{OH} \rightarrow \mathrm{NO}_{2} \rightarrow \mathrm{N}_{2} \mathrm{O} \rightarrow \mathrm{N}_{2}
\end{gathered}
$$

It can be concluded that majority nitrate concentration may be harmful to the population due to the fact that the majority of stomachs are acidic leading to the chemical reactions detailed in Equation (3) and Equation (4). Additionally, the minority of nitrate levels be execrated from human body according to Equation (5) and Equation (6).

Equation (5) and Equation (6) are in accordance with previous reports [65] [66] that demonstrated the efficacy of bacterial to convert $\mathrm{NO}_{3}$ to $\mathrm{N}_{2}$.

The data in Table 2 clearly demonstrate the distribution of cancer cases among population including children. It is obvious that incidence of cancer cases in the present study (Table 2) is nearly higher than the previous incidence rate [38] [50] indicating a growing rate. The explanation of these results is that the population consumed large quantities of bread that contained high concentration of nitrate (Figure 1). Nitrate concentration may be converted in the human body to potential carcinogenic agent such as Nitrite compound according to Equation (3) and Equation (4).

On the other hands, the population consumed large quantities of fresh fruits and vegetable due to their high content of anti-oxidants that would be of beneficial health effects against cancer [52] [67] but for our cases, consumption of fruits and vegetables with high nitrate levels (Figure 2 and Figure 3) may be at 
high cancer risk due to high level of nitrate contents. Our discussion agrees with Song et al. [68] who revealed the potential associations between dietary consumption of nitrates, nitrites, and nitrosamines and gastric cancer. Additionally, they verified that increased consumption of nitrites and $\mathrm{N}$-nitrosodimethylamine seemed to be risk factors for cancer. Furthermore Dellavalle et al. [69] found that high dietary nitrate intake among population expected to have higher exposure to endogenously formed $\mathrm{N}$-nitroso compounds increases risk of colorectal cancer. In the same context Inoue-Choi et al. [70] indicated that high nitrate levels in public drinking water and private well use may increase ovarian cancer risk among postmenopausal women. On the other hand, previous studies on cancer cases have been correlated with pesticides and residues accumulation in agricultural produces [38] [50]. In the present study, it appeared that nitrate levels in food dietary may have a strong correlation with increased cancer cases. Furthermore recent publication [51] correlated the cancer cases many causes.

\section{Environmental Relevance}

Cancer is not a communicable disease but it could refer to as an environmental disease that can be emerged due to exposure to certain environmental pollutants. Accordingly, improving the environmental quality may result in reducing the cancer cases among the population. Improving the environmental quality could be achieved by purifying drinking water by the use of organo-clays [71] [72] [73] bioremediation of soil pollution [74] [75] [76] [77] and the use of cyanobacteria [78] [79] [80]. Implementation of these options may lead to an improvement of the environmental quality and reduction of cancer case.

\section{Conclusions}

The rational of this work emerged from the fact that nitrate levels in food are a leading cause toward a massive carcinoma development in human body. The results revealed high levels of Nitrate residues in bread, vegetables, fruits and water cases in Gaza Strip. A progressive increase of cancer cases in Gaza Strip may be correlated with nitrate levels in bread fruits and vegetables.

It can be concluded that the population in Gaza Strip may become at risk due to high nitrate levels in bread, the main food in Gaza. It is highly recommended to exclude nitrate levels from bread, fruits vegetables and water samples. This can be achieved through reducing the amount of nitrate fertilizers in agricultural system.

\section{Author Contribution}

YE designed, performed the experimental work and wrote the manuscript.

\section{Acknowledgements}

Prof Dr. Y El-Nahhal thanks AvH foundation, Germany. Special thanks go to my students who help me in the data collection and some lab experiments. 


\section{References}

[1] Schecter, A., Papke, O., Ryan, J., Furst, P., Isaac, J., Hrimat, N., Neiroukh, F., Safi, J., El-Nahhal, Y., Abu El-Haj, S., Avni, A., Richter, E., Chuwers, P. and Fischbein, A. (1997) Dioxins, Dibenzofurans and PCBs in Human Blood, Human Milk and Food from Israel, the West Bank and Gaza. Organohalogen Compounds, 33, 457-461.

[2] Schecter, A., Papke, O., Isaac, J., Hrimat, N., Neiroukh, F., Safi, J. and El-Nahhal, Y. (1997) 2,3,7,8 Chlorine Substituted Dioxins and Dibenzofuran Congeners in 2,4-D, 2,4,5-T and Pentachlorophenol. Organohalogen Compounds, 32, 51-55.

[3] Safi, J., Abu Foul, N., El-Nahhal, Y. and El-Sebae, A. (2002) Monitoring of Pesticide Residues on Cucumber, Tomatoes and Strawberries in Gaza Governorates, Palestine. Nahrung/Food, 46, 34-49. https://doi.org/10.1002/1521-3803(20020101)46:1<34::AID-FOOD34>3.0.CO;2-W

[4] Safi, J., Abou Foul, N., El-Nahhal, Y. and El-Sebae, A. (2001) Monitoring of Pesticide Residues on Green Pepper, Potatoes, Vicia faba, Green Bean and Green Peas in Gaza Governorate (PNA), Palestine. Journal of Pest Control and Environmental Sciences, 9, 55-72.

[5] El-Nahhal, Y. (2004) Contamination and Safety Status of Plant and Food in Arab Countries. Journal of Applied Sciences, 4, 411-417. https://doi.org/10.3923/jas.2004.411.417

[6] Safi, J., El-Nahhal, Y., Kaware, M., Abu-Foul, N., Tubael, K. and El-Sebae, A. (2000) Initiation of a Pesticide Environmental Extension and Public Awareness Program for Palestinian Community in Gaza Strip. Journal of Pest Control and Environmental Sciences, 8, 75-98.

[7] Alloh, M.O., AL-Kurdi, S., Alagha, M.R. and Yasser, E.-N. (2018) Nemacur Residue Analysis in Soil Water and Cucumber Samples Collected from the Field in Gaza Strip, Palestine. American Journal of Plant Sciences, 9, 517-530. https://doi.org/10.4236/ajps.2018.93039

[8] Al-Kurdi, S., Al-Louh, M.O., Al-Agha, M.R. and El-Nahhal, Y. (2018) Development of Analytical Method for the Detection of Nemacur Residues in Cucumber Fruits. American Journal of Analytical Chemistry, 9, 64-76.

https://doi.org/10.4236/ajac.2018.91006

[9] Al-Arifi, S.N., Al-Agha, R.M. and El-Nahhal, Z.Y. (2013) Hydrogeology and Water Quality of Umm Alradhma Aquifer, Eastern Saudi Arabia. Environmental Earth Sciences, 3, 118-127.

[10] Al-Arifi, S.N., Al-Agha, R.M. and El-Nahhal, Z.Y. (2013) Environmental Impact of Landfill on Groundwater, South East of Riyadh, Saudi Arabia. Journal of Natural Sciences Research, 3, 222-242.

[11] El-Nahhal, Y., Undabeytia, T., Polubesova, T., Golda Mishael, Y., Nir, S. and Rubin, B. (2001) Organo-Clay formulations of Pesticides: Reduced Leaching and Photodegradation. Applied Clay Science, 18, 309-326. https://doi.org/10.1016/S0169-1317(01)00028-X

[12] Nir, S., Undabeytia, T., Yaron, D., El-Nahhal, Y., Polubesova, T., Serban, S., Rytwo, G., Lagaly, G. and Rubin, B. (2000) Optimization of Adsorption of Hydrophobic Herbicides on Montmorillonite Preadsorbed by Monovalent Organic Cations: Interaction between Phenyl Rings. Environmental Science and Technology, 34, 1269-1274. https://doi.org/10.1021/es9903781

[13] Nir, S., El-Nahhal, Y., Undabeytia, T., Rytwo, G., Polubesova, T., Mishael, Y., Rabinovitz, O. and Rubin, B. (2006) Clays and Pesticides. In: Bergaya, F., Theng, B.K.G. 
and Lagaly, G., Eds., Handbook of Clay Science, Elsevier, Amsterdam, 685-699. https://doi.org/10.1016/S1572-4352(05)01021-4

[14] El-Nahhal, Y., Nir, S., Serban, C., Rabinowitz, O. and Rubin, B. (2000) Montmorillonite-Phenyltrimethylammounium Yields Environmentally Improved Formulations of Hydrophobic Herbicides. Journal of Agricultural and Food Chemistry, 48, 4791-4801. https://doi.org/10.1021/jf000327j

[15] El-Nahhal, Y., Nir, S., Margulies, L. and Rubin, B. (1999) Reduction of Photodegradation and Volatilization of Herbicides in Organo-Clay Formulations. Applied Clay Science, 14, 105-119. https://doi.org/10.1016/S0169-1317(98)00053-2

[16] El-Nahhal, Y., Nir, S., Polubesova, T., Margulies, L. and Rubin, B. (1999) Movement of Metolachlor in Soil: Effect of Organo-Clay Formulation. Pesticide Science, 55, 857-864. https://doi.org/10.1002/(SICI)1096-9063(199908)55:8<857::AID-PS24>3.0.CO;2-P

[17] El-Nahhal, Y., Nir, S., Polubesova, T., Margulies, L. and Rubin, B. (1998) Leaching, Phytotoxicity and Weed Control of New Formulations of Alachlor. Journal of Agricultural Food Chemistry, 46, 3305-3313. https://doi.org/10.1021/jf971062k

[18] Nir, S., Undabeytia, T., El-Nahhal, Y., Polubesova, T., Serban, C., Rytwo, G., Lagaly, G. and Rubin, B. (2000) Optimizing Slow Release Formulations of Hydrophobic Herbicides by Organo-Clays. Annual Meeting, Israel Geological Society, 98.

[19] EL-Nahhal, Y., EL-Najjar, Sh. and Afifi, S. (2015) Impact of Organic Contamination on Some Aquatic Organisms. Toxicology International, 22, 45-53. https://doi.org/10.4103/0971-6580.172256

[20] El-Nahhal, Y., Nir, S., Polubesova, T., Margulies, L. and Rubin, B. (1997) Organo-Clay Formulations of Alachlor: Reduced Leaching and Improved Efficacy. Proceedings of Brighton Crop Protection Conference, Weeds, Vol. 1, 21-26.

[21] El-Nahhal, Y., Mohamed, A. and Samir, A. (2014) Leaching Potential of Diuron and Linuron in Gaza Soils. American Journal of Plant Sciences, 5, 4040-4049. https://doi.org/10.4236/ajps.2014.526422

[22] El-Nahhal, Y., Bayan, W. and EL-Kurdi, S. (2016) Adsorption-Leaching Potential of Chlorpyrifos from Different Organo-Clay. Journal of Encapsulation and Adsorption Sciences, 6, 91-108. https://doi.org/10.4236/jeas.2016.63008

[23] El-Nahhal, Y. and Safi, J. (2008) Removal of Pesticide Residues from Water by Organo-Bentonites. The Twelfth International Water Technology Conference, Alexandria, 1711-1724.

[24] El-Nahhal, Y. (2006) Contamination of Groundwater with Heavy Metals in Gaza. Tenth International Water Technology Conference, Alexandria, 1139-1150.

[25] El-Nahhal, Y. and Safi, J. (2012) Removal of Organic Pollutants from Water by Modified Bentonite. In: Pesticides-Advances in Chemical and Botanical Pesticides, InTechOpen, London, Chapter 5, 93-102. https://doi.org/10.5772/50598

[26] El-Nahhal, Y., Safi, M., Tubail, K. and Safi, J. (2013) Effect of Treated Wastewater Irrigation on Plant Growth and Soil Properties in Gaza Strip Palestine. American Journal of Plant Science, 4, 1736-1743. https://doi.org/10.4236/ajps.2013.49213

[27] Kaschl, A., El-Nahhal, Y., Abu Mourad, T., Tubail, Kh., Safi, J., Hadar, Y., Chen, Y. and Roemheld, V. (1998) Long Term Field Experiment to Examine the Agricultural Application of Municipal Solid Waste Compost in Gaza Strip. Proceedings of Verband Deutscher Landwirtschaftlicher Untersuchungsund forschungsanstalten, Eiladung, KongreBband, 251-254.

[28] El-Nahhal, I., Al-Najar, H. and El-Nahhal, Y. (2014) Physicochemical Properties of 
Sewage Sludge from Gaza. International Journal of Geosciences, 5, 586-594. https://doi.org/10.4236/ijg.2014.56053

[29] El-Nahhal, I., Al-Najar, H. and El-Nahhal, Y. (2014) Cations and Anions in Sewage Sludge from Gaza Waste Water Treatment Plant. American Journal of Analytical Chemistry, 5, 655-665. https://doi.org/10.4236/ajac.2014.510073

[30] El-Nahhal, Y. (2016) Biochemical Changes Associated with Long Term Exposure to Pesticide among Farmers in the Gaza Strip. Occupational Diseases and Environmental Medicine, 4, 72-82. https://doi.org/10.4236/odem.2016.43009

[31] El-Nahhal, Y. (2017) Acute Poisoning among Farmers by Chlorpyrifos: Case Report from Gaza Strip. Occupational Diseases and Environmental Medicine, 5, 47-57. https://doi.org/10.4236/odem.2017.52005

[32] El-Nahhal, Y. (2013) Alcohol like Syndrome: Influence of Increased $\mathrm{CO}_{2}$ Concentration in the Respiration Air. Journal of Environment and Earth Science, 3, 222-227.

http://citeseerx.ist.psu.edu/viewdoc/download?doi=10.1.1.850.9753\&rep=rep1\&type $=\mathrm{pdf}$

[33] El-Nahhal, Y. (2017) Risk Factors among Greenhouse Farmers in Gaza Strip. Occupational Diseases and Environmental Medicine, 5, 1-10.

https://doi.org/10.4236/odem.2017.51001

[34] El-Nahhal, Y. and Lubbad, R. (2018) Acute and Single Repeated Dose Effects of Low Concentrations of Chlorpyrifos, Diuron, and Their Combination on Chicken. Environmental Science and Pollution Research. https://doi.org/10.1007/s11356-018-1313-y

[35] El-Nahhal, Y. (2018) Accidental Zinc Phosphide Poisoning among population: A Case Report. Occupational Diseases and Environmental Medicine. https://doi.org/10.4236/odem.2018.62003

[36] El-Nahhal, Y. and Radwan, A. (2013) Human Health Risks: Impact of Pesticide Application. Journal of Environment and Earth Science, 3, 199-209.

[37] El-Nahhal, Y. and Harrarah, S. (2013) Contamination of Groundwater and Associated Disease: Case Study from Khan Younis Governorate, Gaza, PNA. Journal of Environment and Earth Science, 3, 147-153.

[38] Safi, J., El-Nahhal, Y., Soliman, S.A. and Elsebae, A.H. (1993) Mutagenic and Carcinogenic Pesticides Used in the Gaza Strip Agricultural Environmental. The Science of the Total Environment, 132, 371-380. https://doi.org/10.1016/0048-9697(93)90145-V

[39] Safi, J., Soliman, H. and El-Nahhal, Y. (2000) Surveillance of School Children Prevalence of Infectious Parasites in Beach Camp at Gaza Palestine. Journal of Pest Control and Environmental Sciences, 8, 123-134.

[40] Safi, J. and El-Nahhal, Y. (2000) Contamination of Plant Food by Organic Chemichals: Food Safety Status: Problems and Recommendations. Proceeding of FAO/Regional Workshop on Post-Harvest in the West Asia and North Africa Region, Cairo, 3-6 February 2000, 501-507.

[41] El-Nahhal, Y. (2003) Adsorptive Behavior of Acetochlor on Organoclay Complexes. Bulletin of Environmental Contamination and Toxicology, 70, 1104-1111. https://doi.org/10.1007/s00128-003-0096-z

[42] El-Nahhal, Y. and EL-dahdouh, N. (2015) Toxicity of Amoxicillin and Erythromycin to Fish and Mosquito. Ecotoxicology and Environmental Contamination, 10, 13-21. https://doi.org/10.5132/eec.2015.01.03 
[43] El-Nahhal, Y. and Alshanti, A. (2015) Toxicity of Single and Mixtures Antibiotics to Cyanobacteria. Environment and Analytical Toxicology, 5, 1-8.

[44] El-Nahhal, Y., EL-dahdouh, N., Hamdona, N. and Alshanti, A. (2016) Toxicological Data of Some Antibiotics and Pesticides to Fish, Mosquitoes, Cyanobacterial Mats and to Plants. Data in Brief, 6, 871-880. https://doi.org/10.1016/j.dib.2016.01.051

[45] El-Nahhal, Y., Kerkez, M.F.S. and Abu Heen, Z. (2015) Toxicity of Diuron, Diquat and Terbutryn Cyanobacterial Mats. Ecotoxicology and Environmental Contamination, 10, 71-82. https://doi.org/10.5132/eec.2015.01.11

[46] El-Nahhal, Y., El-Dahdouh, O. and Husam, A. (2017) Influence of Sand Filter in Wastewater Treatment (A Case Study in Gaza City, Gaza Strip Wastewater Treatment Plant). Desalination and Water Treatment, 89, 118-126.

https://doi.org/10.5004/dwt.2017.21398

[47] El-Nahhal, Y. (2017) A New Field Protocol for Determination of Forest Structure, Biodiversity and Heath Status by Means of GPS Tools: A Case Study from Gaza Forest. Open Journal of Ecology, 7, 69-83. https://doi.org/10.4236/oje.2017.71006

[48] El-Nahhal, Y., Lagaly, G. and Rabinovitz, O. (2005) Organoclay Formulations of Acetochlor: Effect of High Salt Concentration. Journal of Agricultural and Food Chemistry, 53, 1620-1624. https://doi.org/10.1021/jf040383a

[49] Ministry of Health (2016) Annual Report. Gaza Strip Palestine.

[50] Safi, J. (2002) Association between Chronic Exposure to Pesticides and Recorded Cases of Human Malignancy in Gaza Governorates (1990-1999). Science of the Total Environment, 284, 75-84. https://doi.org/10.1016/S0048-9697(01)00868-3

[51] Ellulu, M.S., Patimah, I., Khaza'ai, H., Rahmat, A. and Abed, Y. (2017) Obesity and Inflammation: The Linking Mechanism and the Complications. Archives of Medical Science, 13, 851-863. https://doi.org/10.5114/aoms.2016.58928

[52] Bradbury, K.E., Appleby, P.N. and Key, T.J. (2014) Fruit, Vegetable, and Fiber Intake in Relation to Cancer Risk: Findings from the European Prospective Investigation into Cancer and Nutrition (EPIC). The American Journal of Clinical Nutrition, 100, 394S-398S. https://doi.org/10.3945/ajcn.113.071357

[53] WHO (2011) Nitrate and Nitrite in Drinking Water. In: Background Document for Development of WHO Guidelines for Drinking Water Quality, WHO Press, WHO, Geneva. http://www.inchem.org/documents/jecfa/jecmono/v50je05.htm

[54] Sun, S., Ge, X., Xuan, F., Zhu, J. and Yu, N. (2014) Nitrite-Induced Hepatotoxicity in Bluntsnout Bream (Megalobrama amblycephala): The Mechanistic Insight from Transcriptome to Physiology Analysis. Environmental Toxicology and Pharmacology, 37, 55-65. https://doi.org/10.1016/j.etap.2013.11.010

[55] Sun, S., Ge, X., Zhu, J., Xuan, F. and Jiang, X. (2014) Identification and mRNA Expression of Antioxidant Enzyme Genes Associated with the Oxidative Stress Response in the Wuchang Bream (Megalobrama amblycephala Yih) in Response to Acute Nitrite Exposure. Comparative Biochemistry and Physiology Part C: Toxicology \& Pharmacology, 159, 69-77. https://doi.org/10.1016/j.cbpc.2013.09.005

[56] Monserrat, J.M., Martinez, P.E., Geracitano, L.A., Amado, L.L., Martins, C.M.G., Pinho, G.L.L., Chaves, I.S., Ferreira-Cravo, M., Lima, J.V. and Bianchini, A. (2007) Pollution Biomarkers in Estuarine Animals: Critical Review and New Perspectives. Comparative Biochemistry and Physiology Part C: Toxicology \& Pharmacology, 146, 221-234.

[57] Almar, M., Otero, L., Santos, C. and Gonzalez-Gallego, J. (1998) Liver Glutathione Content and Glutathione-Dependent Enzymes of Two Species of Freshwater Fish as Bioindicators of Chemical Pollution. Journal of Environmental Science and Health, 
Part B, 33, 769-783. https://doi.org/10.1080/03601239809373177

[58] Mates, J.M. (2000) Effects of Antioxidant Enzymes in the Molecular Control of Reactive Oxygen Species Toxicology. Toxicology, 153, 83-104. https://doi.org/10.1016/S0300-483X(00)00306-1

[59] Muradian, K.K., Utko, N.A., Fraifeld, V., Mozzhukhina, T.G., Pishel, I.N. and Litoshenko, A.Y. (2002) Superoxide Dismutase, Catalase and Glutathione Peroxidase Activities in the Liver of Young and Oldmice: Linear Regression and Correlation. Archives of Gerontology and Geriatrics, 35, 205-214. https://doi.org/10.1016/S0167-4943(02)00025-0

[60] Chelikani, P., Fita, I. and Loewen, P.C. (2004) Diversity of Structures and Properties among Catalases. Cellular and Molecular Life Sciences, 61, 192-208. https://doi.org/10.1007/s00018-003-3206-5

[61] Sies, H. (1991) Oxidative Stress: Introduction. In: Sies, H., Ed., Oxidative Stress. Oxidants and Antioxidants, Academic Press, San Diego, 15-22.

[62] FAO/WHO (2003) Nitrite (and Potential Endogenous Formation of N-Nitroso Compounds). In: Safety Evaluation of Certain Food Additives and Contaminants, World Health Organization, Joint FAO/WHO Expert Committee on Food Additives, Geneva, WHO Food Additives Series No. 50.

http://www.inchem.org/documents/jecfa/jecmono/v50je05.htm

[63] FAO/WHO (2003) Nitrate (and Potential Endogenous Formation of N-Nitroso Compounds). In: Safety Evaluation of Certain Food Additives and Contaminants, World Health Organization, Joint FAO/WHO Expert committee on Food Additives, Geneva, WHO Food Additives Series No. 50. http://www.inchem.org/documents/jecfa/jecmono/v50je06.htm

[64] Pester, M., Maixner, F., Berry, D., Rattei, T. Koch, H., Lücker, S.,Nowka, B., Richter, A., Spieck, E., Lebedeva, E., Loy, A., Wagner, M. and Daims, H. (2014) NxrB Encoding the Beta Subunit of Nitrite Oxidoreductase as Functional and Phylogenetic Marker for Nitrite-Oxidizing Nitrospira. Environmental Microbiology, 16, 3055-3071. https://doi.org/10.1111/1462-2920.12300

[65] Abed, M.A., Safi, M.N., Köster, J., Beer, D., El-Nahhal, Y., Rullkötter, J. and Garcia-Pichel, F. (2002) Microbial Diversity of a Heavily Polluted Microbial Mat and Its Community Changes Following Degradation of Petroleum Compounds. Applied Environmental Microbiology, 68, 1674-1683. https://doi.org/10.1128/AEM.68.4.1674-1683.2002

[66] El-Nahhal, Y., Awad, Y. and Safi, J. (2013) Bioremediation of Acetochlor in Soil and Water Systems by Cyanobacterial Mat. International Journal of Geosciences, 4, 880-890. https://doi.org/10.4236/ijg.2013.45082

[67] Gonzalez, C.A., Lujan-Barroso, L., Bueno-de-Mesquita, H.B., Jenab, M., Duell, E.J., Agudo, A., Tjonneland, A., Boutron-Ruault, M.C., Clavel-Chapelon, F., Touillaud, M., et al. (2012) Fruit and Vegetable Intake and the Risk of Gastric Adenocarcinoma: A Reanalysis of the European Prospective Investigation into Cancer and Nutrition (EPIC-EURGAST) Study after a Longer Follow-Up. International Journal of Cancer, 131, 2910-2919. https://doi.org/10.1002/ijc.27565

[68] Song, P., Wu, L. and Guan, W. (2015) Dietary Nitrates, Nitrites, and Nitrosamines Intake and the Risk of Gastric Cancer: A Meta-Analysis. Nutrients, 7, 9872-9895. https://doi.org/10.3390/nu7125505

[69] Dellavalle, C.T., Xiao, Q., Yang, G., Shu, X.O., Aschebrook-Kilfoy, B., Zheng, W., Lan Li, H., Ji, B.T., Rothman, N., Chow, W.H., Gao, Y.T. and Ward, M.H. (2014) Dietary Nitrate and Nitrite Intake and Risk of Colorectal Cancer in the Shanghai 
Women's Health Study. International Journal of Cancer, 134, 2917-2926. https://doi.org/10.1002/ijc.28612

[70] Inoue-Choi, M., Jones, R.R., Anderson, K.E., Cantor, K.P., Cerhan, J.R., Krasner, S., Robien, K., Weyer, P.J. and Ward, M.H. (2015) Nitrate and Nitrite Ingestion and Risk of Ovarian Cancer among Postmenopausal Women in Iowa. International Journal of Cancer, 137, 173-182. https://doi.org/10.1002/ijc.29365

[71] El-Nahhal, Y., Nir, S. and Polubesova, T. (1997) Organo-Clay Formulation Is Alachlor: Reduced Leaching and Improved Efficacy. Brighton Crop Protection Conference-Weeds, Brighton, 17-20 November 1997, Vol. 1, 21-26.

[72] El-Nahhal, Y. and Safi, J. (2010) Adsorption of Bromoxynil to Modified Bentonite: Influence of $\mathrm{pH}$, and Temperature. Journal of Pesticide Science, 35, 333-338. https://doi.org/10.1584/jpestics.G09-41

[73] El-Nahhal, Y. and Hamdona, N. (2017) Adsorption, Leaching and Phytotoxicity of Some Herbicides as Single and Mixtures to Some Crops. Journal of the Association of Arab Universities for Basic and Applied Sciences, 22, 17-25. https://doi.org/10.1016/j.jaubas.2016.01.001

[74] El-Nahhal, Y. and Safi, J. (2005) Adsorption of Benzene and Naphthalene to Modified Montmorillonite. Journal of Food, Agriculture and Environment, 3, 295-298.

[75] El-Nahhal, Y. and Lagaly, G. (2005) Salt Effects on the Adsorption of a Pesticide on Modified Bentonite. Colloid and Polymer Science, 283, 968-974. https://doi.org/10.1007/s00396-004-1244-7

[76] El-Nahhal, Y. (2003) Persistence, Mobility, Efficacy and Activity of Chloroacetanilide Herbicide Formulation under Greenhouse and Field Experiments. Environmental Pollution, 124, 33-38. https://doi.org/10.1016/S0269-7491(02)00431-1

[77] El-Nahhal, Y. and Hamdona, N. (2015) Phytotoxicity of Alachlor, Bromacil and Diuron as Single or Mixed Herbicides Applied to Wheat, Melon, and Molokhia. SpringerPlus, 4, 364. https://doi.org/10.1186/s40064-015-1148-7

[78] Safi, J., Awad, Y. and El-Nahhal, Y. (2014) Bioremediation of Diuron in Soil and by Cyanobacterial Mat. American Journal of Plant Sciences, 5, 1081-1089. https://doi.org/10.4236/ajps.2014.58120

[79] El-Nahhal, Y. and Safi, J. (2004) Stability of an Organo Clay Complex: Effects of High Concentrations of Sodium Chloride. Applied Clay Science, 24, 129-136. https://doi.org/10.1016/j.clay.2003.01.002

[80] El-Nahhal, Y. and Hamms, Sh. (2017) Effects of Bromacil, Malathion and Thiabendazole on Cyanobacteria Mat Growth. International Journal of Applied Science-Research and Review, 4, 1. 